\title{
LAPIS-LAZULI FROM SAR-E-SANG, BADAKHSHAN, AFGHANISTAN
}

\author{
By Jean Wyart, Pierre Bariand, and Jean Filippi \\ Translated by Carol Stockton
}

The lapis-lazuli deposits at Sar-e-Sang in Badakhshan, Afghanistan, have provided the raw material for objects fashioned of this stone since the earliest civilizations. The mine, which lies in the Hindu-Kush mountains, is difficult to reach and, because of climatic conditions, is opened only a few months during the summer. The lapis is found in veins in which calcite and dolomite are intimately associated with silicates such as diopside, scapolite, and forsterite. Pyrite is always present; the pure blue mineral is lazurite. The color of the lapis-lazuli varies according to the amount of the various impurities contained therein. Well-formed crystals of lazurite with the dominant $\{110\}$ shape are rarely found. This article examines the crystallographic properties of lapis-lazuli, the site of Sar-e-Sang and the lapis-lazuli deposits there, and offers an explanation for the genesis of the material.

\section{ABOUT THE AUTHORS}

Mr. Wyart and Mr. Bariand are associated with the Laboratoire de Minéralogie-Cristallographie, Universite de Paris VI, France; Mr. Filippi is associated with the Laboratoire de Chimie, Ecole Centrale, Paris, France.

The authors are very grateful to M. Said Hachem Mirzad and his collaborators for their help in enabling the visits to Sar-e-Sang that formed the basis of this article.

An earlier version of this article was published in French in the Revue de Géographie Physique et de Géologie Dynamique, 2. Serie, Vol. 14, No. 4, 1972, pp. 443-448.

(9)1982 Gemological Institute of America
T apis-lazuli is an ornamental stone (figure 1) that has $\mathcal{L}$ been found in the artifacts of some of the oldest known civilizations. Necklaces of this material have been discovered in the neolithic tombs of Mauretania and the Caucasus. The appearance of lapis during archeological excavations in Mesopotamia marks the evolution, economically and artistically, of societies that flourished thousands of years ago in the region of Sumer.

In a well-documented work, Georgina Herrmann (1968) speculated on the possible origins of the mineral and concluded that it came from the mines of Badakhshan, in what is now Afghanistan. Mesopotomia was the commercial center for this treasured material, transformed by its artists into objects of luxury. Thus, more than 4,000 years ago, commercial relations were established between ancient Iraq and Afghanistan, more than $2500 \mathrm{~km}$ to the east. Importation of the blue stone was particularly important at the beginning of the 3rd Dynasty, which marked the apogee of the civilization of $\mathrm{Ur}$, because of the various uses to which the material was put. In the royal cemetery of Ur, excavations revealed fantastic objects fashioned from lapis-lazuli-cylinder seals, necklaces, and statuettes of animals and persons-which testify to the high degree of sophistication attained in sculpture and gem engraving. The abundance of objects of lapis-lazuli in the tombs suggests that this blue stone already possessed a ritualistic value, much as is seen today throughout Iran and the Orient. From Iraq, lapis-lazuli was exported to Egypt during the predynastic period as well as all early dynasties. In Egypt, however, objects formed from lapislazuli have been found only in the tombs of the wealthiest persons. Oriental people, the Hebrews, the Babylonians, and the Assyrians also used this azure stone for ornamentation in the earliest days of their civilizations.

The word lazurium appeared in the sixth century. It is borrowed from the Arab lazaward, which was taken in 


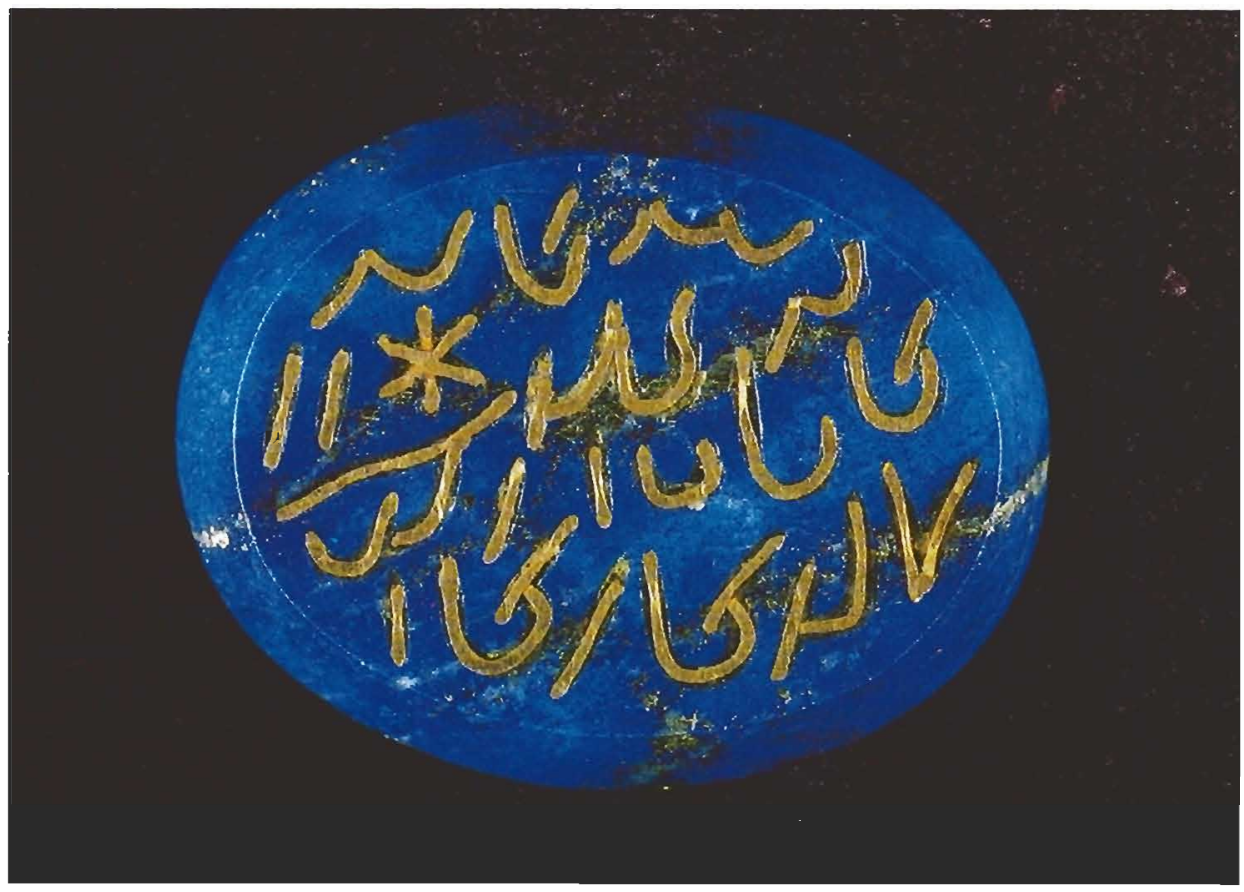

Figure 1. Three-centimeterlong talisman of lazurite with gold writing that was fashioned in Afghanistan in the 19th century. Property of the Paris School of Mines, Paris, France. Photograph 1981 Nelly Bariand.

turn from the Persian lajevard and from which came the word lazul, then azur. As early as the fifth century, the mineral was introduced in Europe under the name ultramarinum, which became ultramarine. Ultramarine served as the most valuable blue pigment and was used by all the great painters until the discovery by J. B. Guimet in 1826 of a method of synthesis that allowed industry to prepare enormous quantities of blue pigment at a low price.

In fact, many lapis substitutes have appeared through the years. These include glass, synthetic spinel, dyed jasper, and the mixture of pyrite fragments with plastic rich in lapis powder. Most recently, Gilson has produced imitation lapislazuli-with and without pyrite-that is quite attractive.

\section{THE LAPIS-LAZULI DEPOSITS}

Apart from those in Badakhshan, a few deposits have been found and occasionally exploited in the U.S.S.R. A deposit situated in the Lake Baikal region (Hogarth, 1970) produces a stone of mediocre quality, but it is too far from Mesopotamia to have been sent there. In 1930, one Russian expedition discovered some lapis-lazuli in the mountains of the Pamir, in a region of very difficult access (Webster, 1962). This deposit has been mined primarily for phlogopite, although medium-grade lapis-lazuli has been recovered as well (Hogarth, 1970).
Little lapis has been found elsewhere in the world. Deposits are known in Chile and Burma, but the quality of these materials is at best mediocre. Lapis-lazuli is also found in San Bernardino County, California, but the original beds were only a few millimeters wide (Rogers, 1938). Thicker veins have been uncovered and the material has been marketed in the U.S. recently, but the quality is such that it is of mineralogical rather than gemological interest. The reader is referred to Sinkankas (1976) for descriptions of this and other North American lapis-lazuli deposits.

The mines of Badakhshan, therefore, are not only among the oldest in the world, but they may also be the most productive and they have historically produced most of the finest-quality material. In addition, because of their location, their mode of exploitation has changed but little over the centuries.

Lapis-lazuli is usually massive and more or less impure. Rather than a single mineral, it is a rock - a mixture of minerals - that varies greatly in composition and color (figure 2). From the physico-chemical point of view, the blue constituent is the mineral lazurite. This mineral has been the object of much study, particularly with regard to its color. To resolve the questions that have arisen, one must use a sample as homogeneous as possible, such as well-formed crystals. But such crystals are rare, because the miners look only for blocks of the blue stone to be carved 


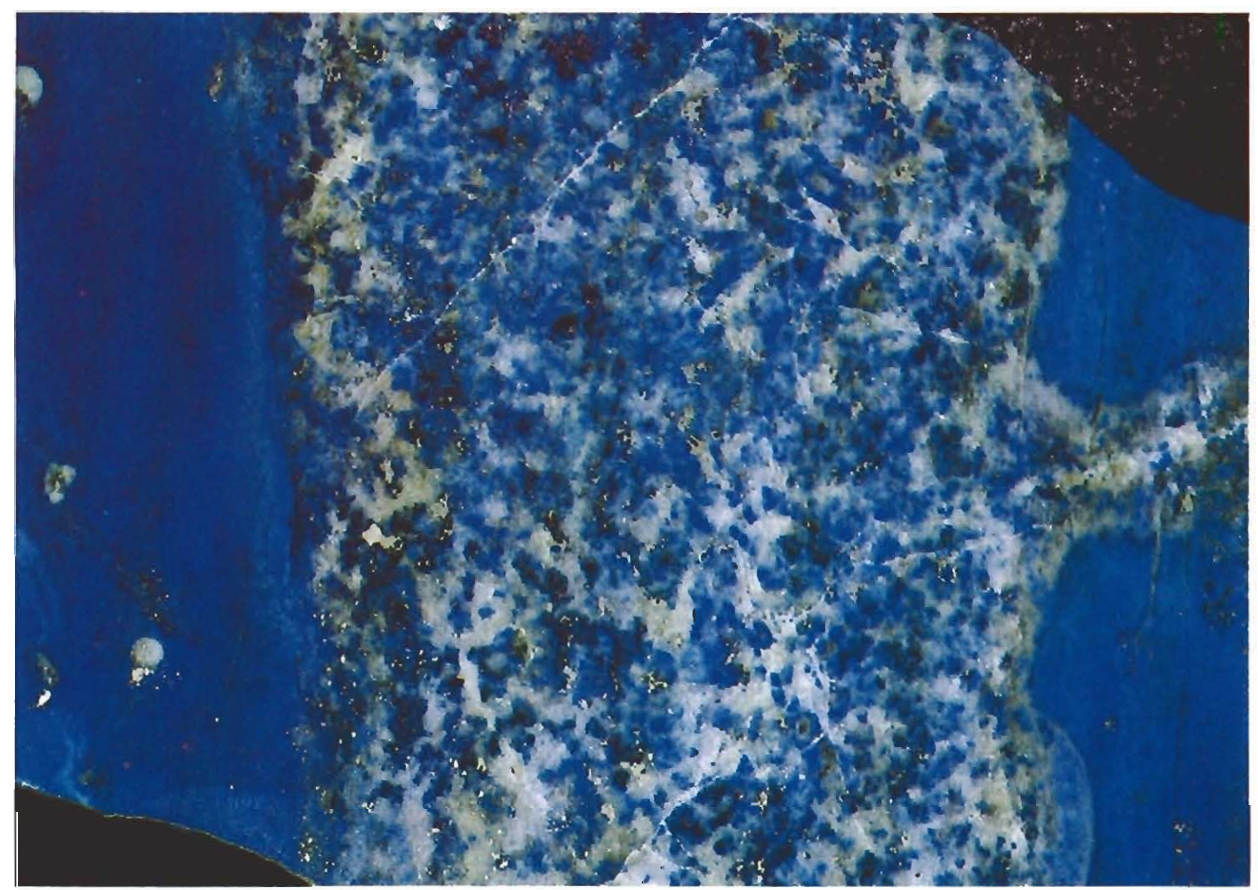

Figure 2. Lazurite slab from Sar-e-Sang, Badakhshan, Afghanistan, $14 \mathrm{~cm}$. Photograph 1981 Nelly Bariand. and polished for jewelry or as objets d'art. It was in search of homogeneous crystals that we undertook expeditions to Badakhshan in 1964, 1967, and 1971. The results of our study of the material found are discussed below, as are the site at Sare-Sang, the mining methods used, and the possible origin and current economic situation of the Afghan stone.

\section{THE CRYSTAL CHEMISTRY AND PROPERTIES OF LAZURITE}

Lazurite belongs to the sodalite group, which are cubic tecto-silicates characterized by the same three-dimensional structure, with the anion $\mathrm{Al}_{6} \mathrm{Si}_{6}$ $\mathrm{O}_{24}$ as the framework motif. The unit cell is 9.0 $\pm 0.1 \AA$. The sodalite group forms a solid-solution series of which the principal end members are sodalite $\left(\mathrm{Na}_{8} \mathrm{Al}_{6} \mathrm{Si}_{6} \mathrm{O}_{24} \mathrm{Cl}_{2}\right)$, nosean $\left(\mathrm{Na}_{8} \mathrm{Al}_{6} \mathrm{Si}_{6} \mathrm{O}_{24}\right.$ $\left.\mathrm{SO}_{4}\right)$, and haüyne $\left([\mathrm{Na}, \mathrm{Ca}]_{8-4} \mathrm{Al}_{6} \mathrm{Si}_{6} \mathrm{O}_{24}\left[\mathrm{SO}_{4}, \mathrm{~S}_{2-1}\right)\right.$. Lazurite is a haüyne rich in sulfur; its ideal composition is $\mathrm{Na}_{8} \mathrm{Al}_{6} \mathrm{Si}_{6} \mathrm{O}_{24} \mathrm{~S}_{\mathrm{X}}$, with $\mathrm{X}$ ranging from 1 to 4 .

The atomic structure of this species was established by Jaeger (1930), and then refined by Pauling (1930), Barth (1932), Machatschki (1933 and 1934), and Saafeld (1961). The $\mathrm{SiO}_{4}$ and $\mathrm{AlO}_{4}$ tetrahedra are linked at their four apexes to form six rings of four tetrahedra parallel to the cube faces and eight rings of six tetrahedra parallel to the faces of the regular octahedron. This alumi- nosilicate structure, common to all the minerals of the group, consists of cuboctahedral frameworks ("cages") in which the large central cavities are occupied by the cations $\mathrm{Na}$ and $\mathrm{Ca}$, and by anions such as $\mathrm{Cl}, \mathrm{SO}_{4}$, and $\mathrm{S}$. This very open atomic structure confers on these silicates the properties of permutites /commonly called "zeolites," or compounds used as water softeners because of their ability to remove "hard" ions from water). They need only be placed in salt solutions of the cations $\mathrm{K}, \mathrm{Li}, \mathrm{Rb}, \mathrm{Cs}, \mathrm{Ag}, \mathrm{Tl}, \mathrm{Mg}$, $\mathrm{Ca}, \mathrm{Sr}, \mathrm{Ba}, \mathrm{Zn}$, or $\mathrm{Hg}$ at $100^{\circ} \mathrm{C}$ for the sodium in them to be replaced by the cations named, with resultant color modification. For example, calcium or zinc replacements result in almost colorless material, while material containing lithium and thallium is very dark.

A toms of sodium and sulfur are found in the large openings in the frameworks, and it is assumed that the atoms of sulfur move in to cavities to form rather unstable radicals such as $\mathrm{NaS}_{2}$, $\mathrm{NaS}_{3,}$ and $\mathrm{NaS}_{4}$. The dissociation of these radicals could then liberate the active $S$ atoms that are responsible for the coloration. Chemical analyses indicate that the greater the percentage of sulfur in the mineral, the deeper the blue. If sulfur is replaced by selenium, the color becomes blood red. Thus the blue color, which usually increases the value of the material as it becomes darker, depends above all on sulfur content as well as on the amount of calcium present. 


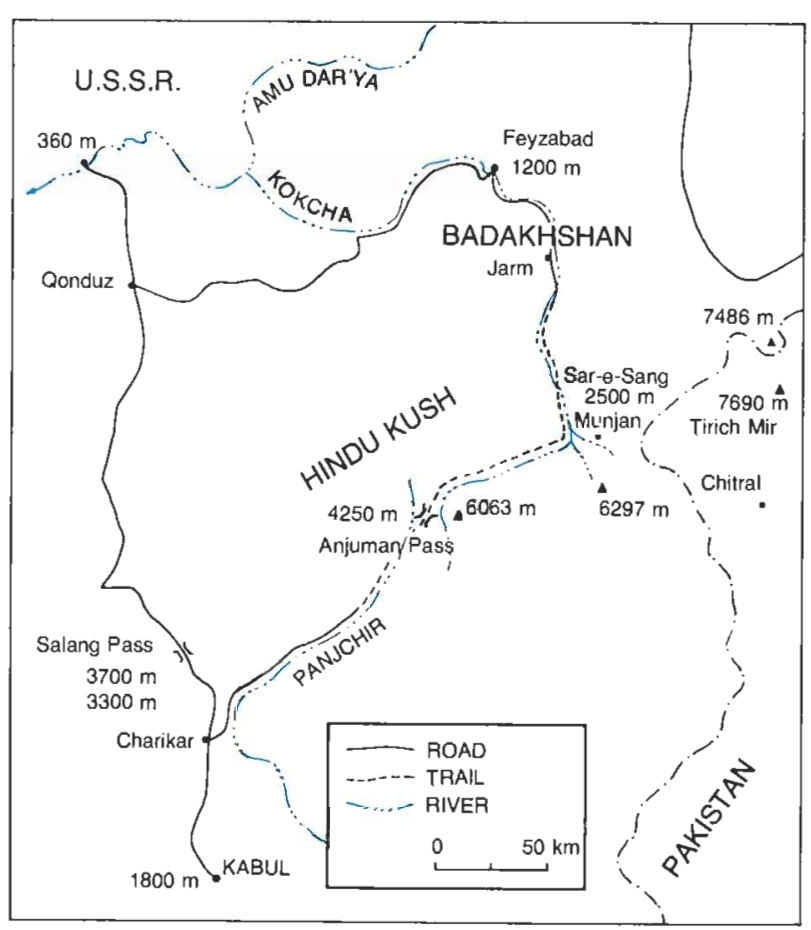

Figure 3. Map of the routes from Kabul to the lapis-lazuli deposits at Sar-e-Sang, Badakhshan, Afghanistan.

\section{THE SITE OF SAR-E-SANG}

Sar-e-Sang is located in Badakhshan, in the northeast of Afghanistan. It lies in the center of the Hindu-Kush massif, along the right bank of the Kolkcha River, which cuts from north to south an anticline with summits reaching $3500 \mathrm{~m}$ to $5500 \mathrm{~m}$. The Kokcha results from the confluence of the Anjuman and Munjan rivers, and empties into the Amu Dar'ya (the Oxus River of the ancients), which demarcates the border with the U.S.S.R. to the north.

This region in Badakhshan was mentioned in Chinese writings as early as the sixth century. From the village of Jarm, situated about $150 \mathrm{~km}$ north of the mines, a commercial route following the corridor of Wakhan leads to Tibet; it connects China with the valley of the Amu Dar'ya and the city of Bokhara. Thus, lapis-lazuli has been used by the Chinese since antiquity.

Marco Polo visited this region of Afghanistan in the 13th century and spoke of a "mountain where the finest azure in the world is found," although he never saw it himself. More recently, the English East India Company lieutenant John Wood (1811-1871) furnished a detailed and picturesque description of an expedition (1836-1838) to the source of the Oxus River in a book pub-

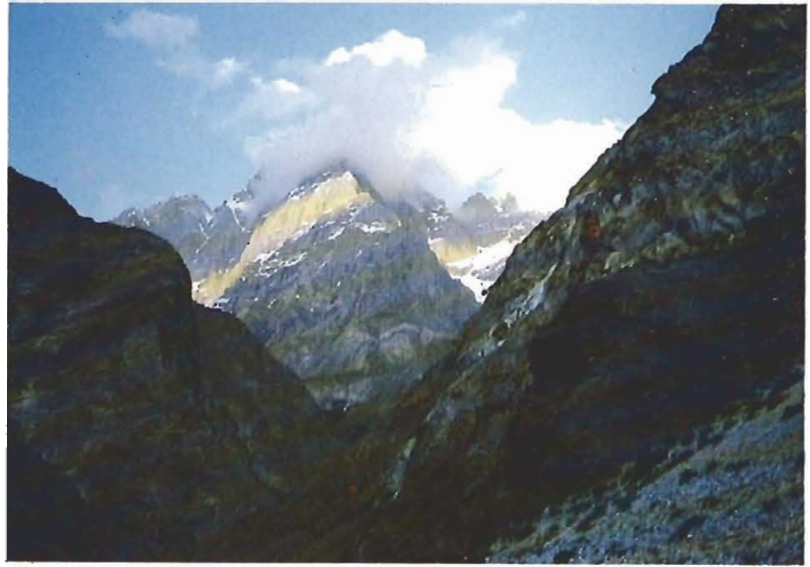

Figure 4. The small valley of Sar-e-Sang. Note the white rocks at the base of this photograph, which are the mine dumps.

lished in 1841. He was the first European to visit the mines and recounted the difficulty of access, the methods of exploitation, and the insecurity for residents and visitors alike. In 1933, French Archeologist J. Barthoux described the lapis-lazuli and "balas" rubies of the Afghan cipolins," and in $1935 \mathrm{~K}$. Brueckl published a study of the mines in the valleys of the Panjchir and Kokcha rivers. In recent years, several members of the French geologic mission in Afghanistan-A. F. de Lapparent, P. Bariand, and J. Blaise (1965) and P. Bordet and A. Boutière (1968)-have furnished interesting information on the region. One Russian mission of five geologists, in the course of two expeditions during the summers of 1963 and 1964, completed a detailed geologic and economic mineralogical study of the Sar-e-Sang region.

Two routes connect Kabul to Sar-e-Sang (figure 3). The shorter route, from the point of view of distance, is to travel by jeep from Charikar, up the valley of the Panjchir, to Dasht-i-Rawat (around $160 \mathrm{~km}$ ), and then to go the final $135 \mathrm{~km}$ to the mine on foot or by horse via Anjuman Pass (figure 4). Undoubtedly, a trail will eventually permit crossing this route entirely by jeep. Currently, the fastest route, which still takes at least four days, begins with a magnificent drive to Qonduz through Salang Pass. From this city, the traveler must follow a difficult road through Khanabad, Taloqan, Feyzabad, and Jarm that terminates

\footnotetext{
- A cipolin is a marble charged with mica, usually of the variety phlogopite and forming a transition between marbles and micas-schists, two rocks that are often associated (as defined by Kemp in C. $M$. Rice, 1951, pp. 75-76).
} 


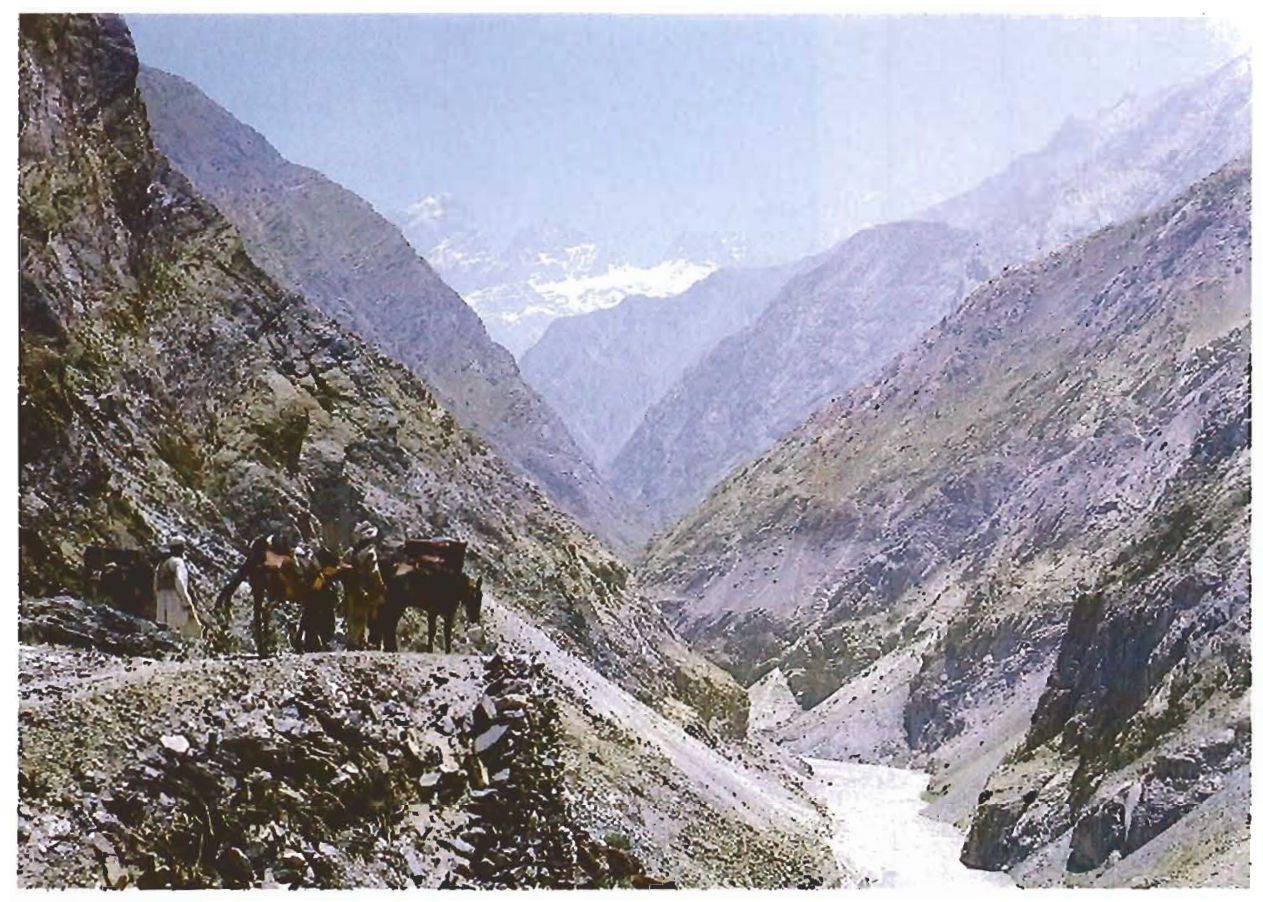

Figure 5. The route through the Kokcha valley, 25 miles before Sar-e-Sang.
3 or $4 \mathrm{~km}$ beyond the village of Hazrat-Said, a distance of about $750 \mathrm{~km}$ from Kabul. A long journey, with horses or donkeys, is then required to climb the $40 \mathrm{~km}$ of narrow and rough trail that follows the gorges of the Kokcha (figure 5).

These two routes are accessible only between June and November. The climatic conditions are such that the royal mine of Sar-e-Sang is exploited at most only five months a year. The camp is located on the right bank of the Kokcha River, at an altitude of $2500 \mathrm{~m}$, near the junction of the river with the stream of Sar-e-Sang. The mine workings, situated between $2700 \mathrm{~m}$ and $3400 \mathrm{~m}$, are difficult to reach. The blocks of lapis-lazuli are brought back to the camp on the backs of men and then transported by donkey to Hazrat-Said.

\section{DESCRIPTION OF THE DEPOSITS}

The Sar-e-Sang complex consists of strongly metamorphosed rocks, with gneisses, cipolins, skarns, crystalline schists, amphibolites, veins of leucocratic granites, and dykes of pyroxenite and hornblendite which are found in enormous blocks in the streambed.

The mountain, which is nearly vertical in slope, is composed of cipolins up to $400 \mathrm{~m}$ thick overlying gneiss. Standing out from the white marbles of the cipolins is a gray band, about $40 \mathrm{~m}$ wide, consisting of skarns in which the lapislazuli occurs. The skarns form beds and lenses, generally 1 - to 2-m-and occasionally 4-m-thick, which usually extend laterally for 20 to $100 \mathrm{~m}$, rarely more than $400 \mathrm{~m}$. The exploitable zones consist of calcite and dolomite associated with forsterite, diopside, and scapolite, often accompanied by phlogopite, sometimes in well-formed crystals up to $2 \mathrm{~cm}$. The blue lazurite is almost always associated with pyrite.

The steep footpath that leads to the main mine (figure 6) ends at a small platform, about $2 \mathrm{~m} \times$ $2 \mathrm{~m}$, at the entrance of a vast cavern that still shows traces of black smoke from ancient mining operations and from which lead the exploited gal-

Figure 6. Access to the mine at Sar-e-Sang.

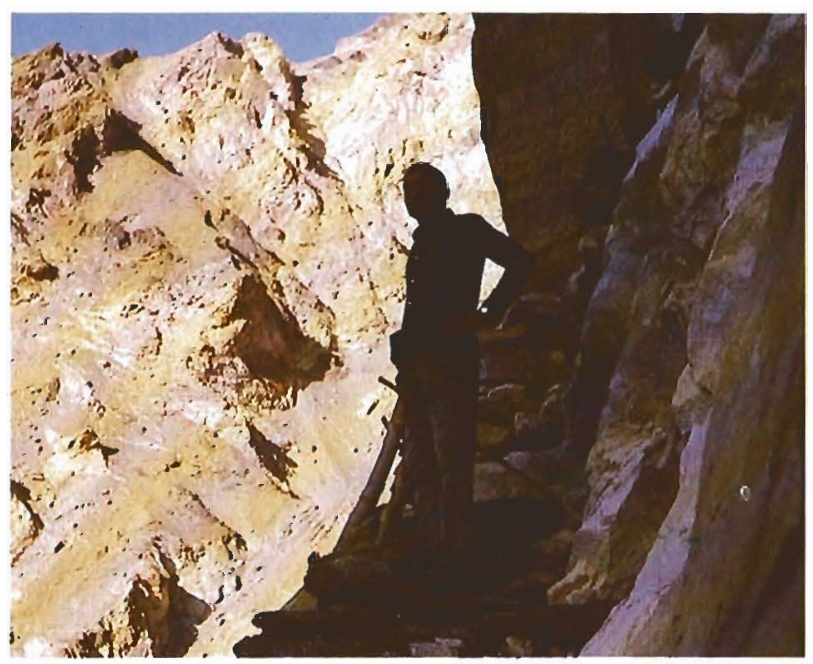




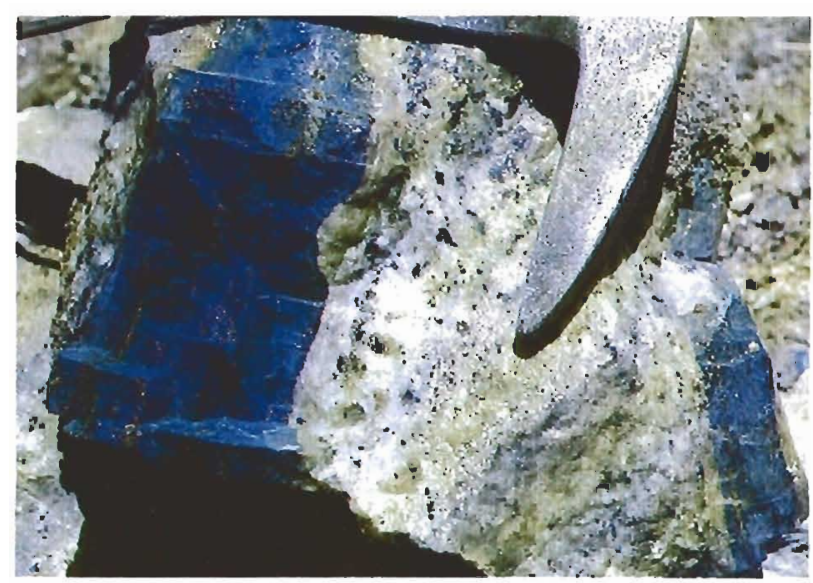

Figure 7. A block of lazurite in the mine dumps at Sar-e-Sang.

leries. The rock is very hard; to break it up, early miners used great wood fires to fracture the limestone. Now dynamite charges are used. The lenses of lapis-lazuli detached from the rock are masses of many kilograms, although they rarely exceed $100 \mathrm{~kg}$. Those less than $10 \mathrm{~kg}$ are relatively homogeneous (figure 7). The zonal structure of the most important lenses recalls their sedimentary origins and the action of metamorphism, because the centers of the larger grains consist of a composite of plagioclase, diopside, calcite, and lazurite, which is surrounded by zones of fine, dark blue grains of lazurite, diopside, and scapolite, with a marginal zone of calcite, diopside, forsterite, and pyrite.

The blocks of rock lacking color are thrown from the platform to the dump $300 \mathrm{~m}$ below, in the Sar-e-Sang streambed. It is in such pieces of cipolin that one must look for well-crystallized lazurite. Single crystals may reach $5 \mathrm{~cm}$ in diameter (figure 8), with the dominant form being the rhombic dodecahedron $\{110\}$, sometimes accompanied by faces of $\{100\}$ and $\{110\}$. A specimen of the mineral afghanite, a species of the cancrinite group, was collected from the region by $\mathrm{P}$. Bariand during an earlier expedition (Bariand, Cesbron, and Giraud, 1968).

\section{NOTES ON THE ORIGIN OF LAPIS-LAZULI}

The regional petrology was described by Blaise and Cesbron in 1966. However, they relied on a detailed study made by Korzhinskij in 1947 regarding the formation of lazurite from the Pre- baikal deposits in the U.S.S.R., which present poor analogies to those of Afghanistan. The following notes are based primarily on our study of the Sar-e-Sang deposits.

The presence of almandine garnet, sillimanite, and kyanite in the schists and gneisses of Sar-eSang indicates a regional metamorphism involving high temperatures and pressures, a conclusion that is shared by all the geologists who have visited the region. The well-formed single crystals of lazurite, with isometric development of faces of $\{110\}$, are formed during metamorphism in a plastic environment in which fluids circulate freely. The original pelitic sediments, and thus the important bed of shale and limestone that overlies them, contained a certain amount of salt water, which with the rise in temperature and pressure during metamorphism transformed the shale into gneiss or granite (Wyart and Sabatier, 1959|, and the limestone into cipolin.

Granitization liberates those solutions whose circulation is facilitated by the tectonic dislo-

Figure 8. A 5-cm lazurite crystal from Sar-eSang, Badakhshan, Afghanistan. Photograph 1981 Nelly Bariand.

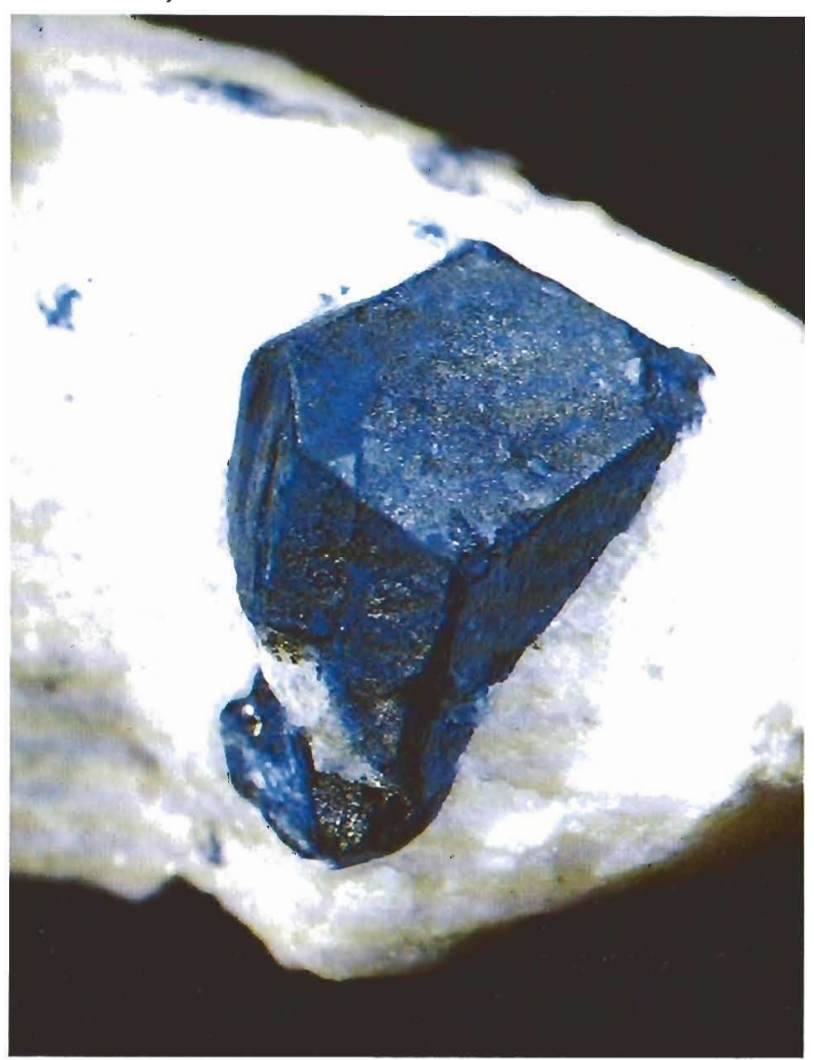


cations. The kaolin of the shale possesses the chemical composition $\mathrm{Al}_{4} \mathrm{Si}_{4} \mathrm{O}_{10}(\mathrm{OH})_{8}$, which approaches the proportions of silica and aluminum in the minerals of the sodalite group. Solutions containing sodium chloride, which are active at relatively low temperatures (on the order of $400^{\circ} \mathrm{C}$ ) as shown by the hydrothermal synthesis of these minerals in the laboratory, readily transform the kaolin into feldspars. However, it is only at higher temperatures that the more or less dolomitic limestones are metamorphosed into cipolins intimately associated with silicates such as diopside and forsterite. These solutions are strongly sulfurous, as is indicated by the consistent presence of pyrite and the presence, less frequently, of sulfides such as galena and molybdenite. It is the presence of sulfur that favors the crystallization of lazurite rather than sodalite, which is found only rarely in these veins. Chlorine, present in the original sediments as sodium chloride, is found in the apatite which always appears, associated with calcite.

\section{THE COMMERCIAL EXPLOITATION OF LAPIS-LAZULI FROM SAR-E-SANG}

Transport of the material from the mine at Sar-eSang, via Jarm and Feyzabad, to Kabul requires at least nine days. Prior to the occupation of Afghanistan by the Russians in late 1979, approximately one ton of lapis-lazuli was extracted annually. About $200 \mathrm{~kg}$ of this material was sold to Afghan lapidaries, and the rest was exported. Sorting by the Ministry of Mines separated the material into five categories, with the highest category priced three times that of the lowest. The first category, comprising about $2 \%$ of production, included massive blocks of deep blue color, without inclusions or fissures; the second category, or $14 \%$ of production, included smaller pieces, not more than $5 \mathrm{~cm}$, with the same characteristics as the first group. These two categories were destined for jewelry. The other categories, which varied from dark blue to light blue, with veins of calcite and with varying proportions of pyrite, were used to make ornamental objects.

Reports from Afghanistan since the Russian occupation indicate that at the time of publication this mountainous area had not been taken over by the Russians and remained under the control of Afghan nationalists. However, it appears that the mines have not been worked during this period. Therefore, it is likely that current legal exports are from old stock. It should be noted that operations to smuggle the material across the border with Pakistan continue now as they have for years past.

\section{REFERENCES}

Bariand P., Cesbron F., Giraud R. (1968) Une nouvelle espèce minérale: l'afghanite de Sar-e-Sang, Badakhshan, Afghanistan. Comparaison avec les mineraux du groupe de la cancrinite. Bulletin de la Société française de Minéralogie et de Cristallographie, Vol. 91, pp. 34--42.

Barth T.F.W. (1932) The structures of the minerals of the sodalite family. Zeitschrift für Kristallographie, Vol. 83, pp. $405-414$

Barthoux J. (1933) Lapis-lazuli et rubis balais des cipolins afghans. Comptes Rendus de l'Academie des Sciences de France, Vol. 196, pp. 1131-1134.

Blaise J., Cesbron F. (1966) Données minéralogiques et pétrographiques sur le gisement de lapis-lazuli de Sar-eSang, Hindou-Kouch, Afghanistan. Bulletin de la Société française de Minéralogie et de Cristallographie, Vol. 89, pp. 333-348.

Bordet P., Boutière A. (1968) Reconnaissance géologique dans l'Hindou-Kouch oriental (Badakhshan, Afghanistan). Bulletin de la Société géologique de France, Vol, 7, pp. 486496.

Brueck1 K. (1935) Ueber die Geologie von Badakhshan und Katagan (Afghanistan). Neues lahrbuch für Mineralogie, Vol. 74, pp. 360-401.

Herrmann G. (1968) Lapis-lazuli: the early phases of its trade. IRAQ, Vol. 30, Part 1, pp. 21-57.

Hogarth P.D. (1970) Mineral occurrences in the western Lake Baikal district, USSR. Mineralogical Record, Vol. 1, No. 2, pp. $58-64$.

Jaeger F.M. (1930) Sur les outremers naturels et artificiels. Bulletin de la Société française de Minéralogie et de Cristallographie, Vol. 53, pp. 183-209.

Lapparent A.F. de, Bariand P., Blaise J. (1965) Une visite au gisement de lapis-lazuli de Sar-e-Sang (Hindou-Kouch, Afghanistan). Comptes Rendus Sommaire et Bulletin de la Société géologique de France, p. 30.

Machatschli F. (1933) Zur Hauynformel. Centralblatt für Mineralogie, p. 145.

Machatschki F. (1934) Kristallstruktur von Hauyn und Nosean. Centralblatt für Mineralogie, pp. 136-144.

Pauling L. (1930) The structure of sodalite and helvite. Zeitschrift für Kristallographie, Vol. 115, pp. 213-225.

Rice C.M. (1951) Dictionary of Geological Terms. Edwards Brothers, Ann Arbor, M1.

Rogers A.F. (1938) Lapis-lazuli from San Bermardino County, California. American Mineralogist, Vol. 23, pp. 111-113.

Saafeld H. (1961) Strukturbesonderheiten des Hauyngitters. Zeitschrift für Kristallographie, Vol. 115, pp. 132-140.

Sinkankas J. (1976) Gemstones of North America, Vol. 2, Van Nostrand Reinhold Co., New York, NY.

Webster R. (1962) Gems, Their Sources, Description and Edification. Butterworth \& Co., Hamden, CT.

Wood J. (1841) A Personal Narrative of a lourney to the Source of the River Oxus. John Murray, London.

Wyart J., Sabatier G. (1959). Transformation des sédiments pélitiques à $800^{\circ} \mathrm{C}$ sous une pression d'eau de 1800 bars et granitisation. Bulletin de la Société française de Minéralogie et de Cristallographie, Vol. 82, pp. 201-210. 